\title{
6. TEACHING STRATEGIES EMPLOYED TO APPROACH A POSTMODERN OPUS. RECITAL I (FOR CATHY) BY LUCIANO BERIO
}

\author{
Loredana Viorica Iațeșen ${ }^{76}$
}

\begin{abstract}
The difficulties encountered by any history of music teacher when tackling postmodern repertoire is a well-known fact. Doubts are only natural. For instance, of the innumerable creators belonging to different cultures, which would be the relevant composers? Furthermore, when finally choosing one representative, on which of his/her works should one focus? And after one particular piece of selected, what is the best way to teach the scientific arguments required for its perception? When the chosen opus fails to distinguish itself through the direct expressiveness of its language, what should one do? What are the works of music considered to be exquisite in terms of technique and expression, with an actual impact on the teaching field? This approach is all the more tedious as the specialized teacher is faced with the lack of any immediate feedback about the importance of some music, as the biggest impediment is the music score itself, which becomes gradually accessible, after numerous auditions and explanatory comments. Therefore, the purpose of this research was to achieve the teaching approach of an opus with direct expressiveness composed during the last decades of the last century: Recital I for Cathy by Luciano Berio. An innovative mezzo soprano and 17 instruments score, which promotes the subtleties existing either in the relationship between themes, dramaturgy and language, or in the correspondence between text and sonority. These are some of the aspects that we intend to tackle in order to help our students understand the postmodern phenomenon by means of Berio's inclusive and synthetic vision. In order to ground our scientific approach, we rely on the well-known quotation technique used by the creator, which, by recalling apparently disparate music, facilitates the process of didactic demonstration. The actual quotation or allusion to different sonorities constitutes a challenge in discovering the general and particular meanings of sound dramaturgy, but especially the deep meanings of the emotional reception of the opus.
\end{abstract}

Key words: postmodern opus, themes, dramaturgy, language, quotation technique, teaching strategies

\section{Argument}

Our study aims at suggesting some teaching strategies in approaching a postmodern opus with reference to Luciano Berio's Recital I (for Cathy), ranging from the very conception of the organization of the scientific approach (general approach to Italian opera, establishment of models and perspectives in the development of musical theatre, problematization of the dramatic art genre, focus on some features of Luciano Berio's biography and vocal-instrumental creation) to the focus on the importance of a creation belonging to the last decades of the past century, which, despite its undeniable specific difficulty of language and expression, is highly accessible and synthetic, and characterized by cultural and

\footnotetext{
${ }^{76}$ Associate Professor PhD., "George Enescu" National University of Arts from Iaşi, Romania, email: iatesenloredana@yahoo.com
} 
artistic openness, which makes it worth considering in the process of exemplifying the sound applications dedicated to the late $20^{\text {th }}$ century music.

\section{Introduction}

\subsection{An incursion into the history of the Italian opera of the past century}

The natural evolution after the verismo movement, which meant accepting the importance of Puccini's work (of which Turandot, 1926, was the highlight), was the concern of the new generations (Bianconi, Pestelli, 1992). A creator such as Wolf Ferrari had been seeking an ingenious solution since 1903, putting his subtle talent at the service of Goldoni's comedies and staging high quality comedies (Le Donne curiose, 1903; I Quattro rusteghi, 1906; Il Segreto di Susanna, 1909 Campiello, 1936). Ottorino Respighi focused mainly on timbre, highlighting the orchestral palette inherited from Rimsky-Korsakov in the fantastic and verismo world of Belfagor (1923) or the neoclassical experience of the symphonic creation that he adapts in Maria Egiziaca (1932) followed by La Fiamma (1934). On the other hand, composers loyal to older music preferred the neo-Gregorian style. For instance, Ildebrando Pizzetti looked for a cantabile recitative in his powerful tragedies, Phèdre (1915, inspired by D'Annunzio), Assassinio nella cattedrale (1958). Along the same lines, in his works La Favola del figlio cambiato (1933) or Giulio Cesare (1936), Gian Francesco Malipiero employed different modes of sound organization against the background of the given song (cantus planus). In his turn, Alfredo Casella, marked by his contact with French music and especially with Igor Stravinsky's work, rejected any romance in La Donna or La Favola d'Orfeo (1932). We should also mention Arrigo Pedrollo, Mario Castelnuovo Tedesco and, in particular, Giorgio Federico Ghedini, who finished his last masterpiece in 1956 (Lord Inferno), preferring to use the sound material in a neoclassical style, without ever neglecting the prerogatives of drama. Unlike the aforementioned creators, a younger generation preferred Puccini's post-romantic sonority (Morris, 1996). For instance, Gian Carlo Menotti, who had emigrated to the United States, and especially Renzo Rosellini, who was noted for his sharp theatrical talent on excellent subjects such as Vortice (1958), Vu du pont (1961) and L'Annonce faite à Marie (1970). Although demanding in dealing with the subject matter, Goffredo Petrassi manifested his lyrical attitude in Il Cordovano (1949), using serial language, a technique that also inspired Luigi Dallapiccola in completing his masterpieces Volo di notte (1940), Il priggioniero (1950), Ulysse ((Bianconi, Pestelli, 1992). On the other hand, an opposition relationship is formed between Nino Rota, who talentedly composes the charming pastiches (Bianconi, Pestelli, 1992) enjoyed by all categories of audience and the difficult language of avant-garde creators such as Luciano Berio, Luigi Nono (creator of Intollerenza 1961 and Al gran sole carica d'amore 1975), Roman Vlad, Sylvano Bussotti, Bruno Maderna and Luciano Chailly (author of the lyrical creations Manteau, L'Idiot, Procédure pénale). 


\section{Musical theatre and instrumental theatre. Models and perspectives}

\subsection{Musical theatre - short history}

In the second half of the twentieth century, musical theatre is the genre that brings together the works of the younger post-war generation composers, who use a heterogeneous material including stage situations, musical and extramusical elements (professional body movements, studied gestures, vocal experiments, mobility of the scenography, metamorphosis of light sources), whether or not associated with a plot or a dramatic conduct, where the visual and gestural components become essential. The year 1960 will mark the birth of avant-garde musical theatre. The experiments from the end of the 1950s embark on a path privileging the multitude of modes of expression under the aegis of a new consciousness of audition induced by serialism, concrete music and open opera. In these opuses, the realization of a dramaturgy is no longer a prerequisite. The term 'musical theatre' (Trubert, 2013, p.1277) may be confusing, as in literature this concept is applied in the absence of an actual distinction among the stage works of the twentieth century, when the historical meanings are not clarified in approaching all theatrical forms with songs, opera, musical comedy. The term Musiktheater was first used by Kurt Weill in 1928, in his collaboration with B. Brecht, which materialized in The Threepenny Opera. Heinz-Klaus Metzger reintroduced the distinction between 'musical theatre and instrumental theatre' (Trubert, 2013, p.1277) in Germany, in the field of contemporary music, the term being mentioned in John Cage's 1958 music conference. In 1969, Marianne Kresting, in the Melos magazine, makes the first general characterization of contemporary musical theatre and suggests the theatricalization of music in order to qualify this genre. In France, the term musical theatre, which is commented on in the Polyphonie magazine of 1948, refers to the relationships within the musical drama in general and designates stage music with certain particular forms of hybridization that are not specific to the twentieth century.

\subsection{Opera at the dawn of postmodernism - a controversial genre?}

In the mid-1960s, opera proposes a retrospective of the history of the genre, aiming at the synthesis of the expressive means even within a single scene. Berio's work consists of a kaleidoscope or a parody of perfectly recognizable musical genres. In Zimmermann's Soldaten, the heterogeneity of the material implies a fragmentation with a teleological function. In order to accentuate the communication with the audience and, especially, to involve them in the actual performance, the composer transforms the genre into an 'opera as ultimate theatre' (Trubert, 2013, p. 1278). Another example of the global exploitation of stage possibilities is Henri Pousseur's Votre Faust, which refers to the existence of a mobile structure in which the possible different performances are chosen according to the audience's decisions. Pousseur imagines a moving opera, in which the five scenes form an actual staircase, articulated by different elements, each scene corresponding to a particular color and sound atmosphere (Trubert, 2013). Also, the instrumentalists are arranged on four different levels and the plot 
allows up to four different versions of the unfolding of the drama, provided with particular climaxes.

Another innovative approach to the dramatic art genre from a sound point of view is the call to the technique of musical quotation. Among the numerous examples we mention Berio's Thema Omaggio a Joyce (1958) and especially Stockhausen's Gesang der Jünglinge (Teen Song, 1955-1956) with reference to the music of Monteverdi, Mozart, Gluck - a parody approach - which emphasizes the technique inaugurated by Kurt Weill in the Threepenny Opera. (Trubert, 2013). Therefore, the approach suggested here is a virtual simultaneity, a synchronous coincidence of sacred archaic and especially conventional music and of frivolous subversive music. 'Opera as a serious genre seems to be collapsing into the abyss, preserving from the history of musical dramaturgy, from the consecrated forms of representation only certain elements, which in turn bear other adaptations. Yet, this language develops from different perspectives, where experiences multiplied around 1960, freeing themselves from the relationship with the plot, becoming musical theatre or instrumental theatre'(Trubert, 2013, p. 1278).

\section{Luciano Berio. Portrait}

\subsection{Biographic highlights}

Born in Oneglia (1925) on the Ligurian coast of Italy, Luciano Berio (Duffie, 1993) acquired the first musical knowledge in the piano field from his father and grandfather, who were organists. In a tense historical period, Berio studied composition at the Milan Conservatory with Giulio Cesare Paribeni and Giorgio Federico Ghedini. During his education he earned his living as an accompanist pianist in singing lessons, where he has the opportunity to meet the American mezzo-soprano Cathy Berberian. The artist became his wife shortly after graduation, and Berio dedicated several pieces that brought out her distinctive voice, until their separation in 1964. A few years later he left for the United States (1952) to study with Luigi Dallapiccola at Tanglewood, introducing himself to the mysteries of serial sound organization (Duffie, 1993). He later participated in the Internationale Ferienkurse für Neue Musik in Darmstadt, where he met Pierre Boulez, Karlheinz Stockhausen, György Ligeti and Mauricio Kagel. The creative atmosphere is opened to electronic music, so that Berio together with Bruno Maderna set up the Milan electronic music studio in 1955 (Studio di fonologia musicale). This was the opportunity to invite a number of important composers to work, including Henri Pousseur or John Cage, and also to have regular electronic music auditions the echoes of which were published in the Incontri Musicali magazine (Smith-Osmond, 1991). In 1962, at Darius Milhaud's invitation, he became a professor at Mills College in Oakland, California, and in 1965 he began teaching at the Juilliard School, setting up the Juilliard ensemble, a band dedicated to contemporary music concerts. An unrelenting creator, Berio never stopped composing and thus built up a reputation, 
so in 1966 he won the Italia Award for the Laborintus II opus for voices, instruments and tape. His unanimous recognition occurred with the 1968 premiere of his masterpiece, Sinfonia. A new stage of his success took place between 19741980, when he led the team of electro-acoustic music specialists of IRCAM, Paris (Smith-Osmond, 1991). In 1987, he set up the Tempo Reale, a music research and production centre based in Florence. For special merits, he became an honorary member of the Royal Academy of Music in London in 1988, he received the Ernst von Siemens award for music in 1989, he was elected a foreign honorary member of the American Academy of Arts and Sciences in 1994, and he became the chairman of the Accademia Nazionale di Santa Cecilia in Rome in 2000. Luciano Berio died in 2003, leaving many unfinished projects.

How should Berio's biography be seen nowadays? In our opinion, the Italian artistic environment in which he was born and raised constituted the emotional and cognitive background necessary for the exploration of new musical territories at the time of his compositional maturity. Also, the mentors who stimulated his interest in deciphering the mysteries of creative art represented an important basis in the subsequent establishment of special relationships with personalities from the musical and cultural world of his time.

\subsection{Short description of his work}

Berio's electronic creation dates largely from his work at the Studio di Fonologia in Milan. One of the most important works he conceived there was Thema (Omaggio a Joyce)-1958, based on Cathy Berberian's reading of James Joyce's novel Ulysses, which may be considered the first electroacoustic composition in Western music history, performed with the help of the voice which is subject to transformations obtained through technological means (SmithOsmond, 1991). A later work, Visage (1961) reveals Berio creating a word-free emotional language, by fragmenting and recomposing a recording of Cathy Berberian's voice. Therefore, the composition is based on the symbolic and representative recording of gestures, vocal inflections, 'from undistinguishable sounds to syllables, from laughter to tears and song, from aphasia to inflection patterns in specific languages: English and Italian, Hebrew and the Neapolitan dialect' (Nicolodi, 1990, p. 303). In 1968, Berio completed $O$ King a composition that exists in two versions: one for voice, flute, clarinet, violin, cello and piano, the other for eight voices and orchestra. The creation was dedicated to the memory of Martin Luther King, who had been murdered shortly before. In the vocal version of this creation, the vocals are first uttered, then the consonants that make up his name, which are then linked to give the complete title of the opus at the end. Shortly after its completion, the orchestral version of the $O$ King was included in Berio's best known work, Sinfonia for orchestra and eight amplified voices. The voices are not used in the traditional manner, but they are enhanced by different effects: parlando, whisper, shout (Smith-Osmond, 1985).

A few years later, Berio completed A-Ronne (1975) for eight singers, a collage in which he emphasized the role of the voice. The work (Horvath, 2009) 
is just one of a series of opuses designed in collaboration with the poet Edoardo Sanguineti. A surprising author if we think that for this piece he provided a text in which there are plenty of quotes from very contrasting sources: Dante (Divine Comedy), Goethe (Faustus), Karl Marx and Friedrich Engels (The Communist Manifesto), James Joyce (Finnegan's Wake), Samuel Beckett (Endgame), etc. Another example of the use of Sanguineti's texts is the opera Coro (Quaglia, 2010), whose premiere took place in 1977, which was composed for orchestra, solo voices and big chorus. The work explores a number of sound motifs in a context of the diversity of traditional music from a variety of regions: Chile, North America, Africa. It is worth noting that the recurrent poetic themes are the expression of passion and suffering, such as the pain of being separated from loved ones, the death of a spouse. A recurrent idea (come and see the blood on the streets) is a reference to a poem by Pablo Neruda, written in the context of the outbreak of the Spanish civil war. Towards the end of his creation, Berio was also interested in the use of live electronic instruments in some of his creations: Ofanim (1988-1992) and Altra voce (1999). The electronic music and the technical components of such pieces were always performed by musicians from the Tempo Reale centre.

\subsection{Theatricalization of Berio's music - Perspectives}

Starting from the 1960s, the shows using serial language impose a new autonomy, distinguishing themselves from the traditional sound organization dogma (Trubert, 2013). While the dramaturgy concept loses its unifying character, the gesture becomes a fundamental parameter. Berio links the experience of instrumental and vocal theatre to the need for expressive coherence. 'Very far from the opera, musical performance itself may become a non-specific form of drama. Testimonies are the musicians' actions, gestures, efforts and stunts, who are ready to perform unusual, chaotic, funny actions that may help or complete the audition' (Berio, 2005, p. 90). Noting, structuring a heterogeneous material and plastic awareness of sound events, going beyond words and gestures, impose new formal landmarks.

Visibly inspired by the concept of musical theatre proposed by the collaboration between Kurt Weill and Berthold Brecht, the musician Berio problematizes on the stage representation of sound dramaturgy, focused specifically on voices, which is highlighted by that psychological subjectivity, which allows a distinction between object and idea, so that the dialectical relationship between theatricality and music becomes constant (Trubert, 2013). If one particularizes the matter, one finds that at the heart of it, conditioned by the simultaneity of distinct events, there is a taste for virtuosity, the roots of which send us back to the issue of voice as a phenomenon. Virtuosity involves two levels: on the diachronic plane, on the one hand, extremely fast figures and, on the synchronous plane, on the other hand, simultaneities, which assume the perception of an effort to grasp the meaning, so that the end result will always be pleasant, irrespective of the auditor's depth. In both cases virtuosity involves the 
conception of an instrumental or vocal articulation, especially of a conceptual nature (Smith-Osmond, 1985).

\subsection{The music-text link in Berio's stage creation}

Berio especially favours a creative approach to music in relation to the text. This hieratic poetics corresponds to three particular features according to the structural phonology terms. The first is 'the multiplicity of meanings at the reading level' (Menezes, 2013, p. 1116). The work cannot exhaust all the meanings at the level of the first reading (auditions). On the contrary, its complexity incites new rediscoveries. Despite the Manichean vision of undeniable truths, the work is perceived as the object of an endless process of sedimentation. Its musical creation and Boulezian phenomenologically complex writing allow the audience to situate themselves in relation to their perception. The title of a work, already chosen, suggests the distance between the music and the text (Flyn, 1975).

The second distinct feature refers to the frequent 'textual redundancy' (Menezes, 2013, p. 1116), where Berio proves once again the proximity to the multitude of interpretations of the linguistic phenomenon. For redundancy plays an essential role in the perception of words. Once reinterpreted in a sound context, being perceived by the audience in the complexity of its utterance, the text will be repeated like the central ideas in mythology. This is the case with Circles, which repeats twice the three poems by E. Cummings, Visage, with the obsessive repetition of the word parole; Sequenza III - Markus Kutter's text is reused in several manners, etc.

The last feature is a certain 'indifference of the music to the text' (Menezes. 2013, p. 1117). It is that Brechtian distance that implies an autonomy of the interdependent systems of signs. A more or less independent syntactic elaboration is thus produced to favour this polysemy in the text-music relationship. We note that Berio's interest in the correspondence between texts with multiple meanings and the evolved chromatic language, with overlaps or associations of complex sound aggregates, raises numerous problems for the audience (Menezes. 2013, p. 1117). From this point of view, Berio was undeniably influenced by James Joyce, a Joyce inventor and builder of words with multiple meanings. Edoardo Sanguineti or Umberto Eco, whose importance is at the level of significance, in the sense of the essential opening of the work to its receptor, were other writers with whom he collaborated. Thus, the simultaneity of possible perceptions in Berio's music is an aspect of his compositional strategies (Flyn, 1975).

\section{Recital I}

\subsection{General approach}

Recital I (for Cathy) is a stage work for mezzo-soprano and 17 instruments. Dedicated to Cathy Berberian, the composition was performed by the musician's wife for the first time on 27 April 1972 in Lisbon, in the Great Auditorium of the Calouste Gulbenkian Foundation. In the play, a singer-actress plays the role of a 
soloist who holds a recital. She enters the stage and discovers that the pianist has not arrived. Accompanied by an off-stage harpsichord, she begins the recital with Claudio Monteverdi's Lettera amorosa and Lamento della ninfa, but stops to look for the pianist. (Fig. no. 1, Luciano Berio's Recital I (for Cathy), excerpt from Lettera amorosa)

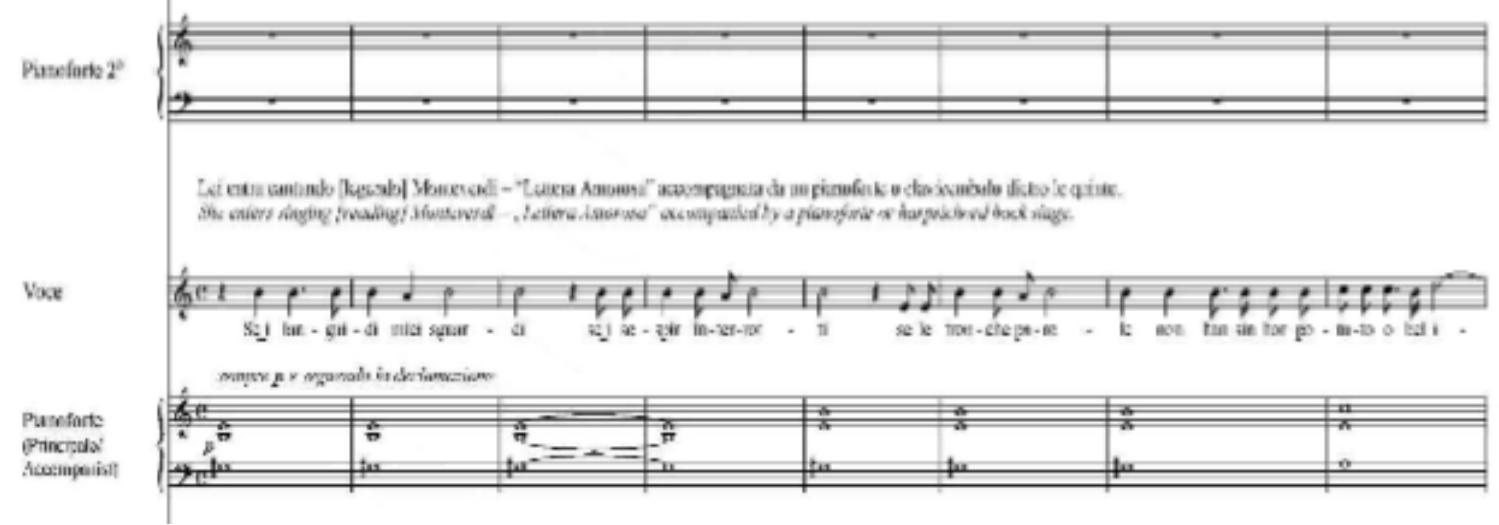

A long spoken monologue follows, which is interrupted by over forty music intermezzi, often very short, taken from Cathy's repertoire, including works that Berio had written for her voice the previous years: Avendo gran disio and Epiphany. (Fig. no. 2, Luciano Berio's Recital I (for Cathy), excerpt from Avendo gran disio)

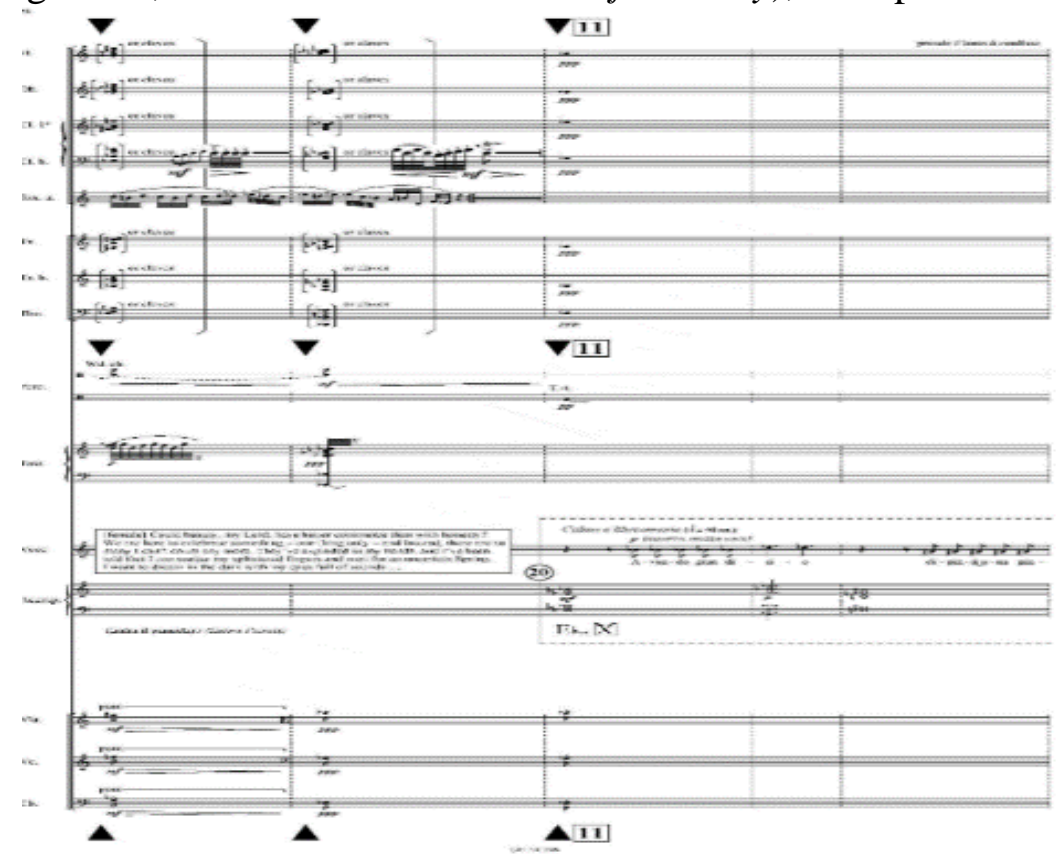

In addition to the sound moments referred to above, we mention other music sources used by the composer: Johann Sebastian Bach, Ich nehme mein Leiden mit Freuden auf mich from the Die Elenden sollen essen BWV 75 cantata; Maurice Ravel, Chanson épique in Don Quichotte à Dulcinée; Henry Purcell, Ye gentle spirits of the air in The Fairy-Queen; Friedrich Hollaender, Ich bin von Kopf bis Fuß auf Liebe eingestellt, as Marlene Dietrich sang in the film Der blaue Engel; Manuel de Falla, Polo in Siete canciones populares españolas; Francis Poulenc, Hôtel in Banalités; Gustave Charpentier, Quelle belle vie in the opera Louise; Alfredo Casella, Quattro Favole Romanesche; Richard Wagner, Träume 
in Wesendonck Lieder; Ambroise Thomas, Je suis Titania in Mignon; Leonard Bernstein, Lamentation in Jeremiah; Gustav Mahler, Oft denk ich, sie sind nur ausgegangen din Kindertotenlieder; Giuseppe Verdi, Cortigiani, vil razza dannata in Rigoletto; Léo Delibes, Bell Song in Lakmé, etc. As the recital progresses, the singer has a fit of insanity, supported by excerpts from Hamlet, Pierrot Lunaire and loss of consciousness scenes in Lucia di Lammermoor by Gaetano Donizetti or taken from the opera Dinorah by Giacomo Meyerbeer. The play ends with a prayer for liberation (Libera nos), its intonation being reduced to a semitone (Metzer, 2003). (Fig. no. 3, Luciano Berio's Recital I (for Cathy), excerpt from Libera nos)

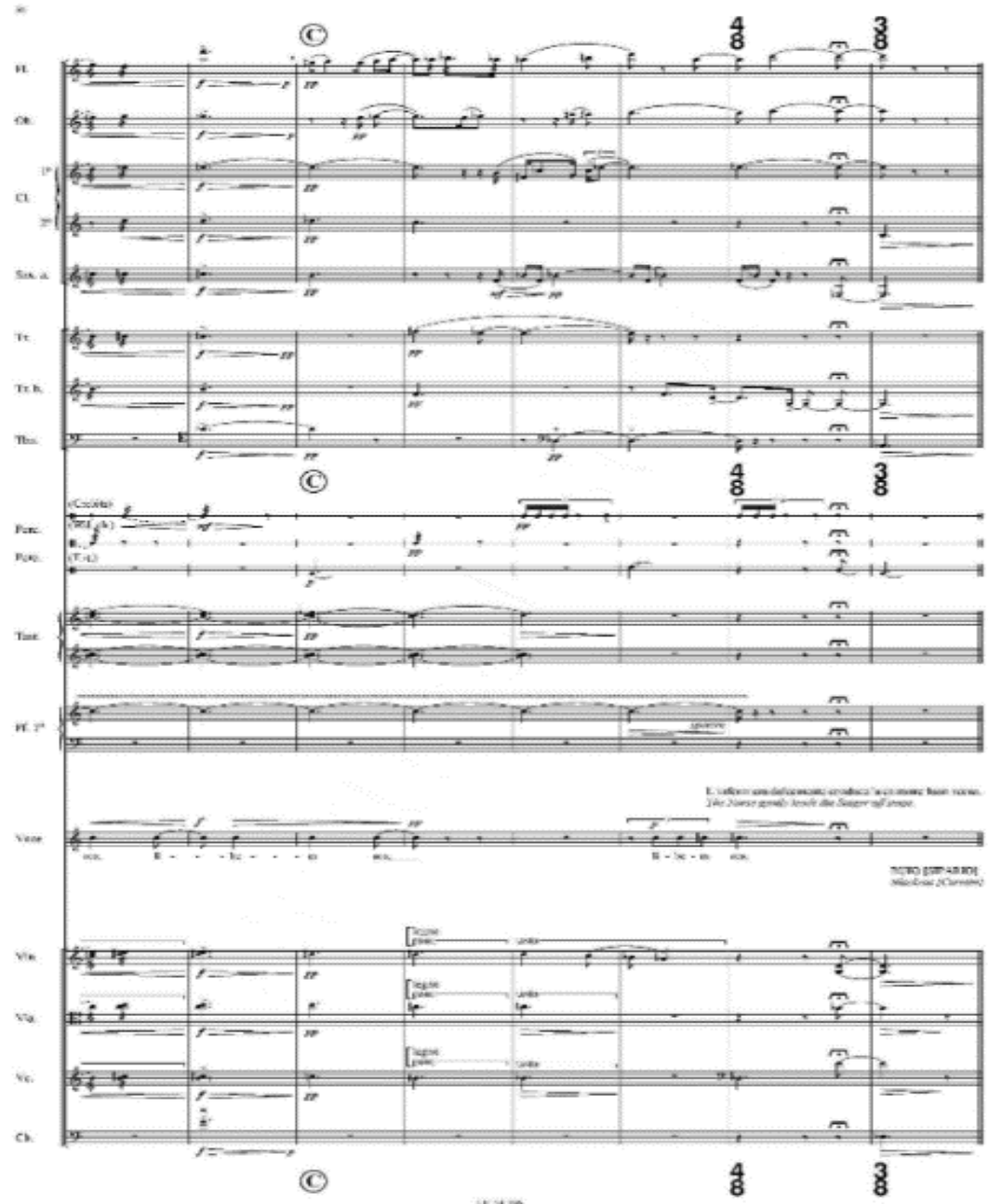

\subsection{Recital I - Stylistic specificity}

Berio chose a slightly different approach when working with Berberien to create Recital I. Berio's final work dedicated to Cathy Berberien highlighted a wide stylistic range and an obvious relationship with the singer's favourite repertoire. The score includes a significant theatrical component, as well as a mixture of musical examples taken from various previous and contemporary sources (Meehan, 2011). According to K. Meehan, taken from Quotation and Cultural Meaning in Twentieth-Century Music signed by musicologist David Metzer, the opus includes ' 47 vocal excerpts alternating with a spoken monologue’ (Metzer, 2003, pp. 219-220). 
The key moments of the opus dramaturgy are relevant in this respect, as the composer chooses to quote or self-quote some significant sound examples from both the stage and the music point of view. Moreover, the musician also seems to be following a chronological historical path in parallel with the evolution of styles. For instance, after the debut in La lettera amorosa by Monteverdi, similarly, Avendo gran disio by Berio forms the highlight of the play. The inclusion of the concentrated sound quotation from Ich bin von Kopf bis Fuss auf Liebe eingestelt, previously performed by Marlene Dietrich, may seem surprising, but it is accounted for by the mosaic-like nature of the text, which focuses on the protagonist in an acute emotional state. A section in which Berberien imitated the artist, as she did in Cage's Aria many years before, with a low and distorted voice. In the Russian excerpts from the music of Stravinsky and Mussorgsky, the protagonist transformed her voice in a guttural play, which contrasts with the clear, focused sound of previous musical examples from Purcell and Schubert. This is a way to offer to the prospective receiver the obvious stylistic contrast between the musical cultures belonging to different areas.

What have we noticed? Just like Sequenza III, Recital I explores the state of maximum over-excitement of a female character. The burden of years of performance and the accumulation of dozens of works in her repertoire are aspects that lead to the creation of the image of an overwhelmed singer who is almost incapable of maintaining control over her recital. Thus, she expresses herself by performing excerpts from other works depicting madness, especially at the end of the score: Lucia di Lammermoor by Gaetano Donizetti and Dinorah by Giacomo Meyerbeer.

As the musicologist Metzer points out in his analysis of music, the numerous quotations serve simultaneously as 'symbols of the singer's madness' (Meehan, 2011, p. 168) and also as 'the source of that agony' (Meehan, 2011, p. 168). Although Cathy Berberian has never experienced the histrionic madness described in Recital, her portrayal of a singer who recalls a life lived on stage is not far from the truth. Like the singer that she depicted, Berberian lived her life on stage and, in certain situations, no longer made the distinction between her public and private life (Vila, 2003). Through the words spoken and the fragmented musical quotes, the protagonist explains, in a kind of stream of consciousness, her stands on art, combined with personal opinions about society, drama, fragments of a mixed discourse. If we rank synthetically the disparate elements of the disparate text, we understand that the audience finally perceives the protagonist as a patient in an asylum, where the wardrobe mistress, who gets to wear her costume, is actually the nurse. In addition to the protagonist, the wardrobe mistress and the pianist, who all act on stage, some instrumentalists also appear. From a musical point of view, the work is a heterogeneous journey through musical quotes extrapolated mainly from Cathy Berberian's repertoire, all contained in a stream of consciousness. Within this text, as suggested by Berberian and the performance instructions provided in the published edition of 
the work, the performers are free to insert their own musical pieces, provided they belong to their vocal repertoire. Therefore, the work is recreated with each new performance.

\section{Conclusions}

Trying to investigate the long and complex processes involved in one of the many stage works for female voice composed in the twentieth century, Recital I (for Cathy), composed by Luciano Berio especially for Cathy Berberian, we draw some conclusions about the musical aspects of the opera, we jotted down some ideas about the score and its genealogy, which were necessary for its teaching approach.

Thus, Recital I expresses its open nature in the subjective play of each performer. The work undoubtedly raises many challenges, both from a vocal and psychological point of view. 'The performer oscillates between recitation and singing, the singing voice acting as a real and spontaneous extension of the actual recitation fragments. At the same time, an unspoken requirement of the work is the possibility to re-create different stylistic worlds and to explore as much as possible - always according to the taste and ability of the performer - the idiomatic palette available for the performer. Therefore, in accordance with the work itself, the performer will provide a thorough reading of the text and will contribute with their own creativity, thus fuelling a flow of consciousness to build a new and personalized meaning' (Placanica, 2014, p. 3).

The score, conceived by Berio as chamber music for soloist, raises obvious challenges in terms of staging and performance. 'Knowing the work and its background involved the need to observe and deconstruct it, it revives the symbolic implications that Cathy Berberian suggested for the play while constructing her musical collage. The music pieces that Berberian first inserted represented her subjective reactions to the meaning conveyed by the monologue' (Placanica, 2014, p. 4). According to her, the text became a fluid material, to which she added a contrasting sound, emphasizing the introspective character.

To what extent can we judge this opus as postmodern? Well, summarizing only a few of the relevant features of the triad music - text - stage play, we note the following: the surreal approach of the subject, the massive presence of improvisation with a role in portraying the character, the status of the lyrical artist in contemporary society, who is often faced with feelings of alienation due to imminent emotional shocks, causing overlaps, distortions; the bringing together of several sides of the personality of a professional lyrical artist, on the one hand, associated with eloquent music on the other, valorised especially in the form of quotations.

\section{References}

1. Berio, T. P. (2005). Luciano Berio Un ricordo al futuro. Lezione americane, Torino: Editura Einaudi 
2. Bianconi, L., Pestelli, G. (1992) Opera, Histoire de l'opéra italien: Les systèmes. L'opéra spectacle, vol. 5, edited by Lorenzo Bianconi, Giorgio Pestelli, Liège: Editions Mardaga

3. Duffie, B. (1993). Composer Luciano Berio A conversation with Bruce Duffie, Chicago, 4 January, wwwbruceduffie.com.

Flynn, G. W. (1975). Listening to Berio's Music, The Musical Quarterly, July, vol. LXI, no. 2, pp. 388-421.

4. Horvath, N. (2009). The "Theatre of the Ear": Analyzing Berio's Musical Documentary A-Ronne, Musicological Explorations, vol.10, British Columbia: University of Victoria, pdfs.semanticscholar.org

5. Meehan, K. (2011). Not Just a Pretty Voice: Cathy Berberien as Collaborator, Composer and Creator, Washington University in ST. Louis, Department of Music, A dissertation presented to the Graduate School of Arts and Sciences of Washington University impartial fulfillment of the requirements for the degree of Doctor of Philosophy May, Saint Louis, Missouri

6. Menezes, F. (2013). Luciano Berio, în: Flo Menezes, Théories de la composition musicale au XXe siècle (pp.1095-1120) vol. 2, sous la direction de Nicolas Donin et Laurent Feneyrou. Lyon: Symétrie

7. Metzer, D. (2003). Quotation and Cultural Meaning in: Twentieth-Century Music Cambridge: Cambridge University Press

Morris, M. (1996). A Guide to Twentieth Century Composers, Hardcover: Methuen Publishing Ltd

8. Nicolodi, F.(1990) Pensiero e giuoco nel teatro di Luciano Berio, in: Fiamma Nicolodi, Orizzonti musicali italo-europei 1860-1980 (pp.299-316). Rome: Bulzoni

9. Placanica, F. (2014).. Female Epiphanies in Twentieth and Twenty First Century Monodrama: Experimental Study and Artistic Production, in: Music in Theory and Practice Volume 9 -th Edition, by Bruce Bernward, Marilyne Saker (Authors), McGraw-Hill Education, 2014, www.musicandpractice.org 10. Smith-Osmond D. (1985). Playing on words: A Guide to Luciano Berio 's, London: Royal Mussical Association

11. Smith-Osmond D. (1991). Berio. Oxford studies of composers 24. Oxford and New York: Oxford University Press

12. Trubert, J. F. (2013). Théatre musical et théatre instrumental, in: Théories de la composition musicale au XXe siècle: (pp. 1269-1295) vol. 2, sous la direction de Nicolas Donin et Laurent Feneyrou. Lyon: Symétrie

13. Quaglia, B. (2010). Transformation and Becoming Other in the Music and Poetics of Luciano Berio. chapter 11, în: Sounding the Virtual: Gilles Deleuze and the Theory and the Philosophy of Music (pp. 227-248) edited by Brian Hulse College of William and Mary, USA and Nick Nesbitt Princeton University, SUA 14. Vila, M. C. (2003), Cathy Berberien cant' actrice, Paris: Fayard 